\title{
Determination of Some Heavy Metals in Barley Locally Grown for Brewing and It's Malt in Ethiopia
}

Tadele Eticha ${ }^{1 *}$ and Ariaya Hymete ${ }^{2}$

${ }^{1}$ Department of Pharmacy, College of Health Sciences, Mekelle University, Mekelle, Ethiopia

${ }^{2}$ Department of Pharmaceutical Chemistry and Pharmacognosy, School of Pharmacy, Addis Ababa University, Addis Ababa, Ethiopia

\begin{abstract}
The concentration of some heavy metals was determined in barley locally grown for brewing and its malt in Ethiopia. The samples were digested in nitric acid and hydrogen peroxide, and analysed by atomic absorption spectrometry equipped with deuterium arc background corrector. The concentrations of $\mathrm{Cd}, \mathrm{Cu}, \mathrm{Mn}, \mathrm{Pb}$ and $\mathrm{Zn}$ in barley, and the levels of $\mathrm{Cu}, \mathrm{Mn}$ and $\mathrm{Zn}$ in malt were above the maximum permissible limits in cereal grains set by Food and Agriculture Organization/World Health Organization except Cd in barley grains from West Arsi Zone. Even though $\mathrm{Cd}$ and $\mathrm{Pb}$ were found in barley grains, they were below the limits of detection in malt. The result of the survey confirmed that the $\mathrm{Cd}$ and $\mathrm{Pb}$ content in locally malted barley do not pose a risk to consumers' health though the bio-important metals could do. However, the levels of heavy metals in locally grown barley and its malt need to be regularly monitored.
\end{abstract}

Keywords: Barley; Heavy metal; Malt; Maximum permissible limit

\section{Introduction}

Some heavy metals have bio-importance as trace elements but the bio toxic effects of many of them in humans are of great concern [1]. Humans are exposed simultaneously to heavy metals from various sources. One exposure route is ingestion of these metals through contaminated food and beverages. Since increased dietary metals intake may contribute to the development of various disorders, there is a necessity for monitoring of these substances in the human diet [2].

Barley is a major staple food crop in the highlands of Ethiopia [3] and the fifth most important cereal crop in the country. Ethiopia is ranked twenty-first in the world in barley production with a share of 1.2 percent of the world's total production. There are two varieties of barley in Ethiopia: food barley for human consumption and malt barley which can be converted into malt; a key ingredient in beer making. Malt barley production in Ethiopia actually has dual purpose: it can be used for food (bread and different traditional dishes) and malting [4].

Barley is, after water, quantitatively the second most important ingredient for beer production [5]. In Ethiopia, Malt barley grain is mainly produced in the southeastern part of Ethiopia in Arsi and Bale administrative zones and supplied to local breweries by Assela Malt Factory which is the only malt plant in the country $[4,6,7]$.

There is no data on the concentrations of heavy metals in barley locally grown for beer production as well as in its malt in Ethiopia. The aim of the present study was to determine the levels of cadmium, copper, lead, manganese and zinc in barley locally grown for brewing and its malt. The results of this study may provide information on metal accumulation of locally grown barley and its malt.

\section{Materials and Method}

\section{Description of the study areas}

The study areas, Arsi, West Arsi and Bale Zones of Oromia administrative region, are located in southeastern part of Ethiopia. West Arsi Zone extends from 60 12' 29" to 7042 ' 55" N latitude and 380 04' 04" to $39046^{\prime} 08^{\prime \prime}$ E longitude. Arsi Zone lies between $6045^{\prime}$ to $8058^{\prime} \mathrm{N}$ latitude and $38032^{\prime}$ to $40050^{\prime}$ E longitude and Bale Zone is located at $5022^{\prime}$ to $8008^{\prime} \mathrm{N}$ latitude and $38041^{\prime}$ to $40044^{\prime} \mathrm{E}$ longitude.
These zones, among the major barley producing regions in the country, supply barley grains to Assela Malt Factory which is located at Assela town which is found in Arsi Zone of Oromia Regional State, Ethiopia.

To conduct the study, letter of permission was obtained from School of Graduate Studies, Addis Ababa University and given to Assela Malt Factory. Then the factory permitted us to collect barley samples as it was being received from Barley Supply Agents and malt samples during packing.

\section{Samples collection}

Barley samples were collected at Assela Malt Factory in January 2011 from barley grains supplied by top barley supplier districts of Arsi and West Arsi zones, and state farms of Bale Agricultural Development Enterprise (Table S1 and Figure S1). Malt samples were also obtained from the factory during packing in a similar manner. Finally, barley grain and malt samples were stocked in plastic containers and taken to a laboratory.

Top three barley supplier districts each zone were Lemu Bilbilo, Digalu Tijo and Honqolo Wabe from Arsi; Kofele, Shashemene and Kore from West Arsi. According to the information obtained from Assela Malt Factory, the selected three districts supplied $71.8 \%$ and 85.3\% of barley produced in Arsi and West Arsi zones, respectively to Assela Malt Factory in 2011. Similarly, Herero, Robie and Sinana state farms of Bale Agricultural Development Enterprise supplied 59.5\% of total barley produced in Bale zone to the Factory.

*Corresponding author: Tadele Eticha, Department of Pharmacy, College of Health Sciences, Mekelle University, Mekelle, Ethiopia, Tel: +251913625 938; E-mail: td.eticha@gmail.com

Received September 23, 2015; Accepted September 28, 2015; Published October 01, 2015

Citation: Eticha T, Hymete A (2015) Determination of Some Heavy Metals in Barley Locally Grown for Brewing and It's Malt in Ethiopia. J Bioanal Biomed 7: 171-173. doi:10.4172/1948-593X.1000139

Copyright: $\odot 2015$ Eticha T, et al. This is an open-access article distributed under the terms of the Creative Commons Attribution License, which permits unrestricted use, distribution, and reproduction in any medium, provided the original author and source are credited. 
Citation: Eticha T, Hymete A (2015) Determination of Some Heavy Metals in Barley Locally Grown for Brewing and It's Malt in Ethiopia. J Bioanal Biomed 7: 171-173. doi:10.4172/1948-593X.1000139

\section{Elemental analysis}

Barley and malt samples were digested according to the methods described by Shar et al. [8]. Samples were dried to constant weight at $105^{\circ} \mathrm{C}$ in an oven overnight. Analytical blanks were prepared in a similar manner, but omitting the test sample. The digested solutions were examined by flame atomic absorption spectrometry equipped with deuterium arc background corrector (PG990, United Kingdom) for cadmium, copper, lead, manganese and zinc levels.

\section{Quality control}

Appropriate quality assurance procedures and precautions were carried out to ensure reliability of the results. Samples were handled carefully to avoid contamination. All glassware and other containers were properly cleaned and the reagents were of analytical grade. Distilled deionized water was used throughout the study. Reagent blank determinations were used to correct the instrument readings. Accuracy of the digestion procedures were verified by examination of the recovery data, spiking analyzed samples with aliquots of metal standards and then reanalyzing the samples. The percentage recoveries lie within the range of $91.4-106.3 \%$ with the percent relative standard deviations less than ten, indicating good accuracy and precision. Limits of Detection (LOD) were calculated as three times the pooled standard deviation of six runs of blank measurements. LODs of $\mathrm{Cd}, \mathrm{Cu}, \mathrm{Mn}, \mathrm{Pb}$ and $\mathrm{Zn}$ were $0.009,0.008,0.02,0.023$ and $0.027 \mathrm{mg} / \mathrm{kg}$, respectively.

\section{Statistical analysis}

The analysis of variance (ANOVA) and Tukey post-hoc test were performed to find differences between the means of samples at 95\% confidence level and to know specifically which groups differed significantly from the other groups. A two-tailed T-test was also performed between the two data sets. Data were analyzed statistically using SPSS $^{\circ}$ statistical package version 13.0.

\section{Results and Discussion}

\section{Levels of heavy metals in barley and malt}

The mean concentrations ( \pm standard deviation) of metals and their maximum permissible limits in cereal grains set by Food and Agriculture Organization/World Health Organization (FAO/WHO) [9] are shown in Table 1 . The average concentrations of metals in barley were $0.148 \mathrm{mg} / \mathrm{Kg}$ for $\mathrm{Cd}, 6.004 \mathrm{mg} / \mathrm{Kg}$ for $\mathrm{Cu}, 0.775 \mathrm{mg} / \mathrm{Kg}$ for $\mathrm{Pb}$, $18.955 \mathrm{mg} / \mathrm{Kg}$ for $\mathrm{Mn}$ and $31.204 \mathrm{mg} / \mathrm{Kg}$ for $\mathrm{Zn}$ while the average metal contents of malt were $6.038,16.175$ and $33.088 \mathrm{mg} / \mathrm{Kg}$ for $\mathrm{Cu}, \mathrm{Mn}$ and $\mathrm{Zn}$, respectively and below the LOD for both $\mathrm{Cd}$ and $\mathrm{Pb}$. In general, the concentrations of all detected metals in both barley and malt samples were above the maximum permissible limits in cereal grains set by FAO/WHO except $\mathrm{Cd}(0.125 \mathrm{mg} / \mathrm{Kg})$ in barley of West Arsi. The comparison of these metals in barley and malt with some previous studies is given in Table 2 .

The metal contents of barley in this study were higher than those reported in other countries such as Britain [10], Poland [11], China [12] and France [13] for Cd; Britain [14], Poland [11] and France [13] for $\mathrm{Pb}$, and China [15] for $\mathrm{Mn}$ and $\mathrm{Zn}$ while other studies reported higher levels of $\mathrm{Cd}[8,15], \mathrm{Cu}, \mathrm{Mn}$ and $\mathrm{Pb}[8]$, and $\mathrm{Zn}[8,12]$. However, the findings of the present work were in agreement with the values reported in other studies [12,15,16] for $\mathrm{Cu}$ and [12] for $\mathrm{Mn}$. The variation in the metal content of barley in different origins might be caused by the differences in soil types on which barley is grown, agrochemical treatments and environmental pollution.

\begin{tabular}{|c|c|c|c|c|c|}
\hline Sample & Cd & $\mathrm{Cu}$ & $M n$ & $\mathrm{~Pb}$ & $\mathrm{Zn}$ \\
\hline \multicolumn{6}{|l|}{ Barley } \\
\hline Arsi & $<$ LOD & $5.238 \pm 0.008$ & $16.650 \pm 0.010$ & $<$ LOD & $29.400 \pm 0.0475$ \\
\hline Bale & $0.318 \pm 0.0029$ & $6.900 \pm 0.0029$ & $21.351 \pm 0.0005$ & $0.775 \pm 0.0012$ & $30.963 \pm 0.0052$ \\
\hline West Arsi & $0.125 \pm 0.013$ & $5.875 \pm 0.005$ & $18.863 \pm 0.013$ & $0.575 \pm 0.025$ & $33.250 \pm 0.0338$ \\
\hline Malt & $<$ LOD & $6.038 \pm 0.008$ & $16.175 \pm 0.013$ & $<$ LOD & $33.375 \pm 0.038$ \\
\hline MPL & 0.21 & 3 & 2 & 0.43 & 27 \\
\hline
\end{tabular}

Table 1: Metal concentrations (mean \pm SD $\mathrm{mg} / \mathrm{Kg}$ ) of the analyzed barley and malt samples, and their FAO/WHO MPL.

\begin{tabular}{|c|c|c|c|c|c|c|}
\hline Sample & Cd & $\mathrm{Cu}$ & Mn & $\mathrm{Pb}$ & $\mathrm{Zn}$ & Reference \\
\hline \multirow[t]{9}{*}{ Barley } & $0.22-1.95$ & $6.29-35.03$ & $15.4-611.78$ & $0.82-5.64$ & $24.82-95.31$ & [8] \\
\hline & $<$ LOD-1.21 & $1.1-11.3$ & $4.6-16.6$ & - & $10.2-23.5$ & [17] \\
\hline & $0.008-0.036$ & - & - & - & - & [13] \\
\hline & - & - & - & $<0.02-0.48$ & - & {$[12]$} \\
\hline & $0.02-0.046$ & - & - & $0.06-0.12$ & - & [14] \\
\hline & $0.023-0.091$ & $3.45-6.33$ & $16.18-26.38$ & - & $35.85-76.10$ & [15] \\
\hline & $0.003-0.007$ & $5.7-6.2$ & - & - & - & [18] \\
\hline & $<$ LOD-0.06 & - & - & $<$ LOD-0.16 & - & {$[16]$} \\
\hline & $<$ LOD-0.318 & $5.238-6.9$ & 16.65-21. 351 & $<$ LOD-0.775 & 29.4-33.25 & Present work \\
\hline \multirow[t]{4}{*}{ Malt } & 0.007 & 3.5 & 10 & 0.04 & 24 & [19] \\
\hline & 0.018 & 2.55 & - & 0.03 & 23.6 & [10] \\
\hline & 0.001 & $5.8-6.2$ & - & - & - & [18] \\
\hline & - & 6.038 & 16.175 & - & 33.088 & Present work \\
\hline
\end{tabular}

Table 2: Literature and present study concentrations of $\mathrm{Cd}, \mathrm{Cu}, \mathrm{Mn}, \mathrm{Pb}$ and $\mathrm{Zn}$ in barley and malt samples (mg/Kg). 
Bio-important elements such as $\mathrm{Cu}, \mathrm{Mn}$ and $\mathrm{Zn}$ contents of malt in this study were higher than the values reported by Cejka et al. [17] in the Czech Republic. In United Kingdom, lower levels of $\mathrm{Cu}$ and $\mathrm{Zn}$ were found in malt [18]. Nevertheless, the concentration of $\mathrm{Cu}$ in this survey agreed with the values reported by Vinas et al. [16]. Metal contents of malt could be distributed into brewing wastes during brewing process. Pilot plant experiments revealed that high heavy metal contents of beer raw materials mostly pass into the residuals (spent grain, trub and yeast) and therefore, only a negligible fraction of them pass into a finished beer (i.e., their content in finished beer is below the allowed limit) [17].

On the other hand, metals such as $\mathrm{Cd}$ and $\mathrm{Pb}$ were below LOD in malt samples in the present study. Unlike this study, low levels of these metals were reported in other studies in the Czech Republic [17], United Kingdom [18] and Spain [16]. The possible explanation of this difference could be related to type of analytical methods employed and malting process. In this study, flame atomic absorption spectrometry which is less sensitive was used for elemental analysis while electrothermal atomic absorption spectrometry was employed in other studies. In addition, in the first stage of malting process, grain is screened and aspirated to remove large and small impurities and thin corns [19]. Zhao et al. [14] demonstrated that surface contamination, introduced during grain harvest, threshing and storage, was the main reason for the high concentrations of some metals in barley grain samples. Surface contamination could occur as a result of atmospheric deposition, and therefore, $\mathrm{Cd}$ and $\mathrm{Pb}$ levels might be reduced in malt due to malting process.

\section{Statistical analysis}

The analysis of variance indicated that the mean values of $\mathrm{Mn}$, $\mathrm{Cu}$ and $\mathrm{Zn}$ in barley from the three areas were significantly different $(\mathrm{p}<0.05)$. Tukey post-hoc test revealed the $\mathrm{Mn}$ and $\mathrm{Cu}$ levels in barley of Bale were significantly higher than that of the other two areas at $95 \%$ confidence level. Zinc content of barley from West Arsi was significantly higher than that of the other areas. The possible explanation for the significant variation could be explained by the differences in soil types across the zones and agrochemical treatments. The high $\mathrm{Mn}$ and $\mathrm{Cu}$ levels in barley of Bale zone might be related to regular agrochemical treatments of the state farms for the improvement of agricultural production. On the other hand, paired $\mathrm{T}$ test indicated that the barley grains from Bale and West Arsi were not significantly different in their $\mathrm{Cd}$ and $\mathrm{Pb}$ content. There was no significant difference between barley and malt samples for their $\mathrm{Mn}, \mathrm{Cu}$ and $\mathrm{Zn}$ content. In general, it was investigated that barley from Bale zone significantly contributed to the $\mathrm{Mn}$ and $\mathrm{Cu}$ contents of malt while barley from West Arsi zone significantly contributed to the level of $\mathrm{Zn}$ in malt.

This study was limited in that the analytical method employed was flame atomic absorption spectrometry which is less sensitive for elemental analysis, specifically for cadmium and lead, compared to other methods of analysis.

\section{Conclusion}

The findings of this study revealed that the detected metal contents of barley grain and malt were beyond the FAO/WHO maximum permissible limits in cereal grains with the exception of $\mathrm{Cd}$ in barley of West Arsi zone. In general, the levels of metals found in barley were in line with the previously reported data. However, the $\mathrm{Cu}, \mathrm{Mn}$ and $\mathrm{Zn}$ contents of malt were higher than that of from other origins.
Accordingly, the regular monitoring of heavy metals in barley and its malt is recommended.

\section{Supporting Information}

S1 file: Top barley supplier districts and state farms from Arsi, West Arsi and Bale administrative zones, southeastern part of Ethiopia to Assela Malt Factory, and sampling procedures.

\section{Acknowledgment}

The authors acknowledge Assela Malt Factory for their cooperation in providing data and samples. The following Universities were acknowledged: The Mekelle University for granting study leave to Mr. Tadele and Addis Ababa University for financially supporting this study.

\section{References}

1. Duruibe JO, Ogwuegbu MOC, Egwurugwu JN (2007) Heavy metal pollution and human biotoxic effects. Int J Phys Sci 2: 112-118.

2. Zukowska J, Biziuk M (2008) Methodological evaluation of method for dietary heavy metal intake. J Food Sci 73: R21-29.

3. Kaso T, Guben G (2015) Review of Barley Value Chain Management in Ethiopia. JBAH 5: 84-97.

4. USDA (2014) Gain: Ethiopian Grain and Feed Annual Report.

5. Wunderlich S, Back W (2009) Overview of manufacturing beer: Ingredients processes, and quality criteria. In: Preedy VR, Beer in Health and Disease Prevention, Elsevier Inc, Burlington.

6. Bananuka J, Mugoya C, Komen J, Virgin I (2005) Biotechnology product development and diffusion in Eastern Africa: Case studies on product development partnerships, BIOEARN Product Development Partnerships Report, Sida.

7. Legese G, Debebe S, Alemu T (2007) Assessing the uncompanative advantage of malt barley production in Ethiopia. Application of a policy analysis matrix. African Crop Sci Conf Proc 8: 1227-1230.

8. Shar GQ, Shar LA, Kazi TG, Afridi HI, Arain MB, et al. (2007) Multielement analysis of Pakistani barley (Hordeum vulgare L.) varieties by flame atomic absorption spectrometry. J Res Sci BZ Univ 18: 69-77.

9. Chandra R, Bharagava RN, Yadav S, Mohan D (2009) Accumulation and distribution of toxic metals in wheat (Triticum aestivum L.) and Indian mustard (Brassica campestris L.) irrigated with distillery and tannery effluents. J Hazard Mater 162: 1514-1521.

10. Adams ML, Zhao FJ, McGrath SP, Nicholson FA, Chambers BJ (2004) Predicting cadmium concentrations in wheat and barley grain using soil properties. J Environ Qual 33: 532-541.

11. Wieczorek J, Wieczorek Z, Bieniaszewski T (2005) Cadmium and lead content in cereal grains and soil from cropland adjacent to roadways. Polish $\mathrm{J}$ Environ Studies 14: $535-540$

12. Wu F, Zhang G (2002) Genotypic variation in kernel heavy metal concentrations in barley and as affected by soil factors. J Plant Nutr 25: 1163-1173.

13. Malmauret L, Parent-Massin D, Hardy JL, Verger P (2002) Contaminants in organic and conventional foodstuffs in France. Food Addit Contam 19: 524-532.

14. Zhao FJ, Adams ML, Dumont C, McGrath SP, Chaudri AM, et al. (2004) Factors affecting the concentrations of lead in British wheat and barley grain. Environ Pollut 131: 461-468.

15. Chen F, Dong J, Wang F, Wu F, Zhang G, et al. (2007) Identification of barley genotypes with low grain $\mathrm{Cd}$ accumulation and its interaction with four microelements. Chemosphere 67: 2082-2088.

16. Viñas P, Aguinaga N, López-García I, Hernandez-Córdoba M (2002) Determination of cadmium, aluminium, and copper in beer and products used in its manufacture by electrothermal atomic absorption spectrometry. J AOAC Int 85: 736-743.

17. Cejka P, Horak T, Dvora J, Culik J, Jurkova M, et al. (2011) Monitoring of the distribution of some heavy metals during brewing process. Ecol Chem Enginer S 18: $67-74$

18. Home-Grown Cereals Authority (2003). Review of food safety issues relating to the supply and market acceptability of UK malting barley and UK malt.

19. Briggs DE, Boulton AC, Brookes AP, Stevens R (2004) Malts, adjuncts and supplementary enzymes, Brewing Science and practice. Woodhead Cambridge, UK. 